\title{
100 years of the Legal History Review
}

\author{
Laurens Winkel \\ Dutch Chair of the Editorial Committee
}

As the senior Dutch editor and Dutch chairman of the Editorial Committee, it is my task to give a short survey of the history of our journal during the last hundred years.

At first sight, it may seem strange that we celebrate today the centennial of our journal, whereas we are publishing this year only the 86th volume. This can be - albeit only partly - explained by the political history of the last century. Before the Second World War, the Tijdschrift voor Rechtsgeschiedenis was not regularly published. The first volume covered the years 1918-1919, the second the years 1920-1921, and no volumes were published in 1926, 1931, 1935, 1938 and 1940. During the German occupation, only three issues for 1941 were published. The fourth issue was printed, but sent to the subscribers only after the Liberation in 1945. During the difficult years following the war, it was not possible to resume immediately the publication of the journal. The first post-war issues were published in 1950 and since that year the Tijdschrift is no longer only a Dutch affair. The editorial process has since then become a close collaboration between Dutch and Belgian legal historians. On the Belgian side, one name has to be mentioned emphatically: Louis Maes who put a great deal of energy in the Tijdschrift during the first post-war period. After 1950, the Tijdschrift was published with nearly perfect regularity. I will come back to the Dutch-Belgian cooperation later on.

In this paper, I only give some additional information, as in three earlier publications, Robert Feenstra (who was editor of the Tijdschrift during 63 years, from 1950 until shortly before his death in 2013), has already given a survey of the main events in the history of the Tijdschrift. Two of those publications appeared in the Tijdschrift". The following pages are merely a modest supplement to those articles and a proof of the fact that every epoch in history addresses different questions. Unfortunately, the pre-war archives of the

1 TvR 36 (1968), p. 9-30; TvR 62 (1994), p. 21-31; R. Feenstra, L'histoire d'une revue d'histoire du droit, Histoire de l'histoire du droit, Actes des Journées internationales de la Société d'Histoire du Droit, Toulouse 2006, p. 401-407. 
Tijdschrift which were kept with the publisher Tjeenk Willink have not been preserved. Part of the post-war records are kept at the National Archives in The Hague and I have seen the most important documentation contained in that collection. But let me follow the chronology.

In the first issue in 1918, the Editorial Committee made a declaration which evidently reflects the tendency towards internationalism, apparently as a result of the Dutch general policy towards the end of the First World War. The Netherlands were neutral during the war, but there was a general tendency towards internationalism and under the influence of scholars such as T.M.C. Asser much was achieved in the fields of international collaboration and international law. One example was the building of the Peace Palace in the Hague, in 1913. The same international orientation and idealism can be perceived in the declaration of the Editorial Committee, which was most probably written by E.M. Meijers. Meijers was without doubt the key figure of the journal's four founding fathers. The declaration mentioned the evident need for international collaboration, also in legal-historical studies, not only in order to strengthen the international character of legal history, but also in view of showing the relevance of legal history to legal practitioners. At the same time, the declaration was a plea for legal history as a truly academic topic in the university curriculum, which was about to be reformed in the Netherlands at the time ${ }^{2}$.

In the first issue of the Tijdschrift (four issues were planned each year), we find an article written by Meijers on the medieval university of Orléans, which was destined to become a captivating topic for at least two generations of Dutch and Belgian legal historians. Not only post-war editor Robert Feenstra devoted many publications to that university, but a whole series of doctoral dissertations of his pupils focussed on various aspects of the university and its law school. Among these, I should mention the Leyden dissertation by our Belgian co-editor Laurent Waelkens (1984), the dissertations and other important publications by the Leyden legal historian Kees Bezemer, by Corrie Ridderikhof, by Marguerite Duynstee (since 1991 our editorial secretary), and by our informal text editor for more than half a century, Liesbeth van Soest ${ }^{3}$. I will be

2 The result was the so-called Academisch Statuut of 1921. Roman law and Dutch legal history were from now on compulsory topics in the curriculum in Dutch law schools.

3 L. Waelkens Théorie de la coutume chez Jacques de Revigny, Leyde 1984; C.M. Ridderikhoff et H. Ridder-Symoens, ed., Premier Livre des Procurateurs de la Nation germanique de l'ancienne Université d'Orléans 1444-1546. Première partie: Texte des rapports des procurateurs, [Les Livres des Procurateurs de la Nation germanique de l'ancienne Université d'Orléans 1444-1602 publiés par le Comité international pour l' histoire de la Nation germanique de l'Université d'Orléans], Leiden 1971 (several other volumes were published); C.HM. Bezemer, Les répétitions de Jacques de Révigny, Leyde 1987; M.C.I.M. Duynstee, L'enseignement du droit civil à l'Université d'Orléans du début de la guerre de Cent ans (1337) au siège de la ville (1428), Frankfurt/ 
short on the pre-war editors of the Tijdschrift. In his speech of 1968, Feenstra made the point that the editors were not from Leyden only, but were coopted among legal historians and Romanists of other universities as well. The four main editors, however (Meijers, Van Oven, and, after the Second World War, Fischer and Feenstra) had one feature in common: all were alumni of the University of Amsterdam.

I make an exception here for the founder J. van Kan, an interesting ${ }^{4}$ scholar with many contacts abroad who was responsible for the international fame of our journal. He was the author of a standard work on the history of the codification in France (a book written in French ${ }^{5}$ ) and in 1924 he was a key figure in the Law School in Batavia ${ }^{6}$. He deserves an intellectual biography! Meijers wrote his obituary for the Royal Dutch Academy of Sciences in almost poetic terms ${ }^{7}$ :

A man then without notion of the time which is bestowed upon us on this earth, and without sufficient reflection on the topics that have to be put forward during this short period. Or perhaps just someone with more awareness of the temporal aspects than we, poor mortal human beings tormented by the temporal character of our existence on earth. Someone who is aware of the transitory character of all that is created by human beings, someone who has chosen to devote himself totally to the themes which pleased him and who enjoys every detail of scientific research, someone who is even aware that the cubic meters of stone that one carries for the construction of the temple of sciences are perishable and forgotten, but who has tried and found the greatness and tragedy of human existence in nearly all aspects of life and who has discussed all this with his audience and contemporaries.

Main 2013; L.J. van Soest-Zuurdeeg, La Lectura sur le titre De actionibus (Inst. 4,6) de Jacques de Révigny: édition du texte, précédée de prolégomènes, Leyde 1989.

4 He was not only an expert in Dutch and European legal history, but he also paved the way for the study of colonial legal history, especially in the Dutch East Indies.

5 A.H.M.J.(= J.) van Kan, Les efforts de la codification en France, Étude historique et psychologique, Paris 1929. Quelques articles préparatoires furent publiés dans la TvR: J. van Kan, De verwachting des volks in 1789 ten aanzien van de codificatie, TvR 1 (1918), p. 359-389; idem, Stemmen voor de codificatie onder de regering van Lodewijk XVI, TvR 2 (1920), p. 149-162; idem, Le rôle de l'initiative privée dans l'œuvre de la Révolution en matière de codification et de constitution, TvR 3 (1922), p. 215-234; idem, Une seconde tentative de codification sous Louis XV, TvR 5 (1924), p. $76-79$.

6 The predecessor of the modern Univeritas Indonesia in Jakarta.

7 E.M. Meyers, Levensbericht A.H.M.J. van Kan, in: Jaarboek KNAW, 1944-1945, Amsterdam, p. 205-216; the quotation p. 215-216. 
Now some words on the ban of the publication of the Tijdschrift during the first years of the German occupation. Feenstra wrote in 1968 that the German authorities vetoed further publication ${ }^{8}$. Indeed, such a measure is probable in 1941 and has to be understood in connection with the Jewish background of the de facto chief editor Meijers. No mention was to be made of his name on the front page of the journal. Strangely enough, Meijers published in the same year 1941 an article on the Glossators and Equity. He also wrote the obituary of the founding editor De Blécourt. Moreover, in 1941, the journal published articles written by refugee German Jewish legal historians such as the Romanist Fritz Schulz, who had fled to England, Walter Ullmann, who had also fled to England, and by the Romanist Hans Julius Wolff, who first fled to Panama, and later to the USA. In that sense, the year 1941 is by far the most curious volume of the Tijdschrift and it is as it were a forerunner of the standard work Jurists uprooted, on the forced emigration of German Jewish jurists 9 . How these manuscripts reached the office of the Tijdschrift will most probably remain for ever unknown. Maybe they had been sent already before the outbreak of the war in Holland in May 1940. Exchange of letters between England, the USA and the occupied Netherlands was not totally impossible, but very time consuming and laborious. It is therefore possible that the manuscripts of those articles were received even after the German invasion.

Meijers was not only editor of the Tijdschrift, but also of the Dutch private law journal WPNR, and he was annotator of the Nederlands(ch)e Jurisprudentie, in which important judicial decisions, mainly of the Dutch Supreme Court, were published. In the somewhat apologetic book of Meijers' attorney during the war, Mrs. Van Taalingen-Dols ${ }^{10}$, no mention is made of the Tijdschrift. However, Cleveringa's famous speech in November 1940, one of the first public speeches in which the German occupiers were severely criticised at Leyden University, was triggered by the dismissal of Meijers as a professor in Leyden at the behest of the German authorities. Cleveringa's speech was recently commemorated by Professor Marian Schwegman ${ }^{11}$. The speech contains a reference to the first publication by Meijers, in the first volume of the Tijdschrift, on Cornelis van Bynkershoek's Observationes Tumultuariae. That work which is

8 See the editorial in TvR 1950, $\mathrm{nr}$ 1: “... toen de bezetter verdere activiteiten verbood" (when the occupier forbade further activities).

9 J. Beatson \& R. Zimmermann (ed.), Jurists uprooted, German-speaking emigrant lawyers in the twentieth-century Britain, Oxford 2004.

10 L.M.I.L. van Taalingen-Dols, De strijd om een mensenleven 1940-1945, Goes 1960.

11 M. Schwegman, Cleveringa en Meijers: een weerbarstige geschiedenis van getuigen en overleven, Leiden 2017. 
now a particular area of interest to our co-editor Boudewijn Sirks, sometime Regius Professor for Civil Law in Oxford.

Further attention is paid to ancient reports of judicial decisions in an article by Meijers on the history of Private International Law, in volume 3 of the Tijdschrift (1922). Here also, we see the beginning of a tradition: the numerous publications on the Great Council of Malines may be viewed as a continuation of the pre-war interest in the history of judicial decisions, to which the postwar editors Strubbe and De Smidt devoted much of their research. In our time we refer to the chronological lists of the decisions of the Great Council and the Amsterdam dissertation by Alain Wijffels, currently our senior Belgian editor $^{12}$.

I return now to the time immediately after the Second World War: a visit of the Belgian legal historian Louis Maes (on 30 October 1948) to professor Fischer was a decisive moment. Fischer immediately reported the visit to Meijers. In a later letter (3 January 1949) he wrote to the latter: "without your support nothing will happen". This was the beginning of the Dutch-Belgian collaborative work, but it appears from the records how difficult it was to set it up. Each visit to Belgium was under control of the Ministry of Finance, which had to grant that foreign currency were made available in small amounts through the Dutch Central Bank. How difficult this is to imagine in our time after Schengen and the introduction of the euro! All that lasted until at least the end of 1953, although there were alleviations in the allowance of foreign currency from 1949 onwards. The Belgian government granted, I think, earlier than the Dutch government a somewhat more substantial financial support to this new form of Dutch-Belgian partnership in the field of legal history. I have the impression that the mutual relations between the editors became less formal after the death of Meijers in 1954. In the records, we find a very formal letter on the possible transport of Meijers in Robert Feenstra's car towards the beginning of the nineteen-fifties. After 1953, informal relations within the Editorial Committee prevailed, first names were used and the spouses of the editors were involved as well. All this was undoubtedly due to Robert Feenstra, the very active Dutch secretary of the Editorial Committee since 1950, who took care that the semiannual Committee meetings which took place alternatively in Belgium and the Netherlands, were interrupted by a decent, sometimes even gastronomic, lunch. This tradition has been continued until this very day and is one of the reasons for the very good internal relations within the Editorial Committee.

12 A. Wijffels, Qui millies allegatur - Les allégations du droit savant dans les dossiers du Grand Conseil de Malines (causes septentrionales, ca 1460-1580), I+II, Amsterdam - Leiden 1985. 
The selection of Dutch editors was at that time a complicated affair. According to an informal note of a telephone call made by Feenstra with H.J. Scheltema in 1953, it appears that he only wanted to join the Editorial Committee if Meijers and Van Oven - who had both retired as university professors at the time - would withdraw from the Editorial Committee. In Scheltema's view, all editors had to be active professors. That view was not followed, but it did not prevent Scheltema publishing in 1955 his remarkable programmatic article on the new edition of the Basilica in the Tijdschrift. Meijers and Van Oven remained members of the Editorial Committee until their death in 1954 and 1962, respectively.

From the Dutch side, the editors were after 1950: Meijers, Van Oven, Fischer and Feenstra. Meijers was succeeded in 1956 by P.W.A. Immink, who in his turn was succeeded by Piet Gerbenzon in 1965. After the death of Frits Fischer in 1964, Felix Wubbe, who wrote in 196o the first Leyden thesis on Roman law after the war in Leyden and was awarded a cum laude after the defence, became a member (which he remained until 1993). In the meantime, he was appointed to a chair in Roman law at Fribourg in Switzerland. The Belgian members of the Editorial Committee were François Ganshof, John Gilissen, Louis Maes and Egidius Strubbe, although the names of Emile Lousse and Gérard Fransen also appear in the records. For unknown reasons, they eventually did not take up any formal responsibilities in the Tijdschrift. In 1962, Maes left the Editorial Committee and he was replaced by Raoul van Caenegem (member of the Committee during 45 years, until 2008). He has recently passed away and the Tijdschrift will publish posthumously one of his last articles [86 (2018), p. 339344]. In 1988, Gilissen died at the age of 75 . He had been, together with Louis Maes, the stimulator of the Tijdschrift on the Belgian side. Philippe Godding succeeded Strubbe in 1977 and remained an editor until 1997. Jos Monballyu, a specialist in the history of criminal law, became a member of the Editorial Committee in 1988 as Gilissen's successor. He retired in 2007. In 1982, Olav Moorman van Kappen succeeded to Piet Gerbenzon. He retired from the Editorial Committee in 2010. Jeroen Chorus was a member of the Editorial Committee during his Leyden professorship, from 1986 until 1993.

We have by now reached the present time. With Dirk Heirbaut (successor of Van Caenegem) and Serge Dauchy (successor of Jos Monballyu) we have - in addition to Waelkens and Wijffels, both already mentioned - two outstanding Belgian legal historians in our midst, whereas the Dutch editors Jan Hallebeek, Boudewijn Sirks and Remco van Rhee take part in our work since ten, respectively twenty years. A substantial part of their work focuses, as in Heirbaut's and Dauchy's case, on late-medieval and early-modern legal history. Hallebeek is particularly interested in medieval law, in particular canon law, Van Rhee is 
a specialist in the history of procedural law, and Sirks has an expertise in the reception of Roman law. For classical and postclassical Roman law, our editors Sirks and Waelkens have built a reputation of strong competence.

Next to the Editorial Committee, an Editorial Board exists a form of collaboration with foreign legal historians was already in place since 1929. I only mention here the names of the legal philosophers Roscoe Pound and Hans Kelsen, and the Belgian professor François Ganshof. Before the War, Second World War, the Editorial Board of the revived journal was created in $195^{\circ}$ and consisted of almost all the professors in legal history in the Netherlands and Belgium, probably due to the new setup. It consists now of former members of the Editorial Committee.

A few episodes in the history of the Tijdschrift remain to be mentioned. Retrospectively, the discussion on (e.g.) the ink spot in the papyrus of the Pauli Sententiae (BPL 2589) is amusing. In the issue 1957 (2), David and Nelson reacted on the very critical review by Scheltema of their edition of that papyrus. Was it really an ink spot? Notwithstanding the at times fierce character of the discussion, Scheltema published a significant article on Byzantine law in the same issue.

Time and again, The Legal History Review has acted as an innovator for a new approach in legal history. In 1922, the Italian Romanist and legal historian Zocco Rosa published new fragments of some of the most important vestiges of ancient Greek legislation, the law of Gortyn on Crete. An important fact indeed! That same year, we also find a survey of publications in the field of legal history in the United States, which illustrates the bridge-function of the Tijdschrift already during the very first years of its existence. A year later (in 1923), the English guest lectures "General problems of the codification of Justinian", held by the French Romanist Paul Collinet at the University of Oxford, were published in the Tijdschrift ${ }^{13}$.

The Tijdschrift has been a mirror of its time. Let us give three examples:

(1) In view of the later history of the Netherlands during the Second World War, it is an irony that we find in the second volume of the Tijdschrift a review written by the prominent Utrecht Professor D.G. Rengers Hora Siccama of the doctoral thesis of K.J. Frederiks on old Dutch criminal law. The former was for a long period a well-known professor of legal history at Utrecht, but he fell under the spell of Nazi-ideology during the Occupation. The second was a pupil of S.J. Fockema Andreae Sr. in Leyden, the founding father of the renewed study of Dutch legal history after the reform of the academic legal curriculum in 1921. Frederiks was Secretary-General of Internal Affairs during the German occupation and he was criticized after the war.

13 The general problems raised by the codification of Justinian, $\operatorname{TvR} 4$ (1923), p. 1-30. 
(2) A second example. The first German scholar who offered an article to the Tijdschrift after the Second World War was thoroughly screened: Karl Wellschmied, a pupil of Hans Thieme offered an article on Grotius' Introduction to Dutch Jurisprudence. In the archives, one finds a note by Fischer where he writes that no risk must be taken by publishing an article by an author who might have misbehaved during the German occupation. Wellschmied turned out to have been stationed in the Netherlands as a member of the German military forces. However, no documented objections could be found and the article was published in 1954 (2). After him, several other German legal historians and Romanists published articles in the Tijdschrift without any further discussion.

(3) A third example of the mirror function of the Tijdschrift: in 1954 (issue no. 2), an article written by the well-known Dutch historian Jan den Tex was published: Oldenbarnevelt, un meurtre judiciaire? In the correspondence with the Editorial Committee and in the article itself, we find references to the criminal proceedings against Marshall Pétain ending with his lifelong banishment to Ile d'Yeu ... ${ }^{14}$. A case of $\beta$ ío $\pi \alpha p \alpha \dot{\lambda} \lambda \eta \lambda$ or featuring Van Oldenbarnevelt and Pétain?

There was also continuity in the Tijdschrift before and after World War II. Pier Severio Leicht (1874-1956), a successful and important Italian legal historian, published as early as 1923 in the Tijdschrift on Italian research in legal history. That same year, he joined Mussolini's fascist party and he became a Member of Parliament, and later Secretary of State for Education. When the regime changed, he lost his licence to teach, as well as a number of his honorary functions. From a postcard now preserved in the National Archives, it appears that he continued to offer his services to the Tijdschrift. I have not found that his offer had any effect, perhaps because of his old age, but political reasons cannot be excluded. His only contribution to the Tijdschrift was a bibliographical article in French offering a survey of Italian literature on legal history during the decade 1940 to 1950, published in the Tijdschrift 1951 (issue no. 3).

Now something about the name of our journal. From the beginning, it also had a French title: Revue d'Histoire du Droit, and since 1972, there is also an English title: The Legal History Review. Communications of the Editorial Committee therefore are published in three languages, which can be somewhat laborious. In the Tijdschrift, authors can publish in Dutch, French, German, English, Italian, Spanish and Latin. H.J. Scheltema has so far been the only scholar who has taken advantage of that last possibility: in 1941 (issue no. 4), he wrote in Latin on a topic of Byzantine law. Later, however, he published in 
German a very polemical article directed against Adolf Berger. The controversy turned around the binding legal force of the Basilica and the question whether the Emperor Leo the Sage had abolished Justinian's legislation.

Articles on antique Roman law and on later legal history are more or less in balance in the older volumes, but also in more recent years. Whereas the method of legal history has not changed very much over the past hundred years, the opposite applies to the study of Roman law. Before the war, Gerhard Beseler had published article in the Tijdschrift (1930 (1): Romanistische Studien). He was a champion in reporting interpolations and much - though not all - of his work is now considered completely outdated. After the war, the neo-humanistic approach to Roman law gradually came to prevail. Here, the name of Max Kaser has to be mentioned. In the work of this prominent Romanist, the change of paradigm is perfectly illustrated: his articles on the Roman law of pledge (in Tijdschrift 1976 and 1979) are emblematic of the modern approach to Roman legal sources, particularly in relation to the fragments of Roman jurists collected in the Digest.

A striking phenomenon in the last few years: our authors are no longer only from Europe and North America. Formerly, contributions would occasionally be sent from South Africa. Nowadays, our authors are also scholars from South America and now and again from Asia. The present-day outlook of the Tijdschrift is at first sight quite comfortable. Many more articles are submitted than we could possibly publish. The editorial policy of the Committee can therefore be reasonably severe with regard to the articles which are eventually published. The fact that the Tijdschrift belongs to the so-called scientific Ajournals is nearly self-evident. Nevertheless, we should also have some concerns for the future, for example regarding the requirements of direct accessibility of research funded by public financial means. Those requirements could eventually be a threat for the publication of scientific journals by commercial editors. However, let us not end on a pessimistic note.

Ladies and Gentlemen, it is time to conclude this survey. Until now, I have been a laudator temporis acti, I have written in praise of the past of our journal. On the occasion of a jubilee, another Latin proverb imposes itself: tempora mutantur et nos in illis: times are changing and we change within those times. Hence we shall proceed with speeches discussing the development of scientific publishing, not least in the field of legal history; and this afternoon, Professor H.-P. Haferkamp, from Cologne, will give a survey on the changes in the study of legal history during the last hundred years. 